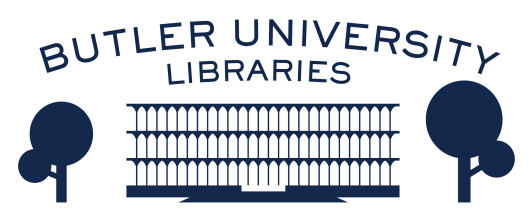

Journal of Hindu-Christian Studies

Volume 14

Article 14

January 2001

\title{
Book Review: "Religious Conversion, Contemporary Practices and Controversies"
}

Ronald Neufeldt

Follow this and additional works at: https://digitalcommons.butler.edu/jhcs

Part of the Religion Commons

\section{Recommended Citation}

Neufeldt, Ronald (2001) "Book Review: "Religious Conversion, Contemporary Practices and Controversies"," Journal of Hindu-Christian Studies: Vol. 14, Article 14.

Available at: https://doi.org/10.7825/2164-6279.1257

The Journal of Hindu-Christian Studies is a publication of the Society for Hindu-Christian Studies. The digital version is made available by Digital Commons @ Butler University. For questions about the Journal or the Society, please contact cbauman@butler.edu. For more information about Digital Commons @ Butler University, please contact digitalscholarship@butler.edu. 


\section{BOOK REVIEWS}

\section{Religious Conversion, Contemporary Practices and Controversies. Christopher Lamb and Darrol Bryant (Eds.). London and New York: Cassell, 1999, 342pp.}

\begin{abstract}
AS THE INTRODUCTION states the purpose of this volume is to explore religious conversion in terms of its theoretical meaning, its significance within religious traditions, and the tensions it creates in society. To these ends the volume is divided into three parts. Part One deals with theoretical perspectives. Lewis Rambo and Charles E. Farhadian offer their theory of stages of conversion. Donald Taylor, through the categories of inward, outward and awkward conversion attempts to explain how the word conversion is used and understood in ordinary conversation. Frank $\mathrm{K}$. Flinn examines conversion in the Pentecostal and charismatic movements, challenging in the process reductive interpretations of that have neglected social and cultural factors.
\end{abstract}

Part Two examines conversion in the world's religions. Here we find perspectives from Buddhism (Christopher Lamb), from Judaism (Rodney Mariner), from Chinese religion (Jordan Paper), from the Zoroastrians in India (Homi B. Dhalla), from the Hindu/Gandhian perspective (K. L. Sheshagiri Rao), from Islam (Yasin Dutton), and from the Sikh tradition (Doris $R$. Jakobsh). This last chapter of Part Two is particularly interesting in that it explores the Punjabi Sikh attitudes to western converts to Sikhism.

Part Three offers four chapters on conversion within Christianity. M. Darrol Bryant offers an overview of conversion in the history of Christianity, charting in the process the changing understanding of conversion in Christianity. Karla Poewe examines charismatic conversion in the light of Augustine's Confessions offering in the process her own views on the dangers inherent in an emphasis on experiential religion. Irving Hexham deals with Isaiah Shembe's conversion, placing this into the context of the development of the African Independent Churches and into the crosscultural context of conversion in Christianity. Macrina Sitzia examines the meaning of conversion from the perspective of the Benedictine vow "connversio morum."

Part Four offers seven chapters on contemporary cases. Graham Harvey argues that coming out Pagan is not conversion. Rather it is a case of discovering who or what one has always been. Through the examination of his own journey from the Church of England to the Catholic Church Tim Edgar speaks of conversion as a process of becoming rather than radical change. Darshan Signh Rudel recounts her movement from a Catholic background in southern France to conversion to Sikhism. Martin Eggleton deals with conversions to new religious movements and the controversies surrounding those conversions. Tamal Krishna Goswami recounts his experience of conversion to ISKCON and the experience of being a western convert to a Hindu tradition. Lorne L. Dawson examines the controversies surrounding cult conversions through a running commentary on the transcript of a 1979 CBS programme entitled Cults: Choice or Conversion. Sophie Gilliat-Ray addresses the rediscovery of Islam by contemporary young Muslims in Britain. Given the personal nature of some of the chapters, this is perhaps the most engaging section of the volume.

It is impossible to deal with every paper in a volume of this size. I will therefore 
confine myself to selective comments on themes and chapters. On the theoretical level the volume does an excellent job of distinguishing between ethnic and universal religions, pointing out that conversion is more apt to be associated with the universal religions. There is in this context the interesting suggestion that in Hinduism we may see a move from the ethnic to the universal in that conversion is a relatively recent phenomenon introduced by groups like the Arya Samaj. The tendency of the volume is to deal with conversion from and conversion to. Little attention is given to the phenomenon of assimilation or adoption a phenomenon that results in claims that one can belong to more than one tradition. Jordan Paper does pay attention to this in his chapter, but argues that assimilation and adoption should not be seen as conversion. This is, admittedly a debatable point. However, it should be noted that in the controversies over conversion in India, Indian scholars have treated assimilation and adoption as forms of conversion. Also, with the exception of the chapter by Paper and the chapter by Tim Edgar, not enough attention is paid to the business of conversion within, that is a movement from one indigenous or related community to another.

The paper on conversion in
Zoroastrianism provides a wealth of information on the controversy surrounding the idea of conversion in that tradition. Unfortunately, it tends to recite uncritically what might be seen as Hindu nationalist notions on the constitutional provisions for religious freedoms and the rather troublesome notion that religious minorities in India live there at the pleasure of the religious majority. The chapter on Gandhi, while making an important distinction between real conversions and harvesting souls, ignores much of the scholarly work that has been done on Gandhi with respect to his attitudes to other religions. Harvey's argument that coming out pagan is not really a conversion, but a discovery of who one has always been is suspect. After all, similar language is used in both conversion accounts and in accounts of enlightenment.

The issues cited in the paragraph above notwithstanding this is an excellent volume, one that should be on the shelf of any scholar or student interested in conversion. Perhaps its strongest point is that it is written in a style that makes it accessible both to scholars and to lay persons.

\author{
Ronald Neufeldt \\ University of Calgary
}

\section{Beyond Orientalism. Fred Dallmayr. Albany: State University of New York} Press, 1996, xxiii $+277 \mathrm{pp}$.

IN THE LAST TWO decades, the exposure of Orientalism carried with it an implicit hope. Like Freud's hope in the exposure of the unconscious, much post-Orientalist writing implied that new ways of imagining others might be possible once bias had been identified. However, if the late 90's are any indication, identity politics between the "West" and the "East" have become worse and not better. But there are occasional books that take the responsibility of constructive engagement seriously and creatively. Beyond Orientalism is one of them. Fred Dallmayr has written a set of erudite and bold essays in the theory of cross-cultural encounters which can move us toward the next wise steps in the minefield of cross-cultural engagement.

Dealing mostly with India as his dialogical partner, Dallmayr's chapters move methodically through a series of issues central to cross-cultural engagement: models for the representation of the other; the nature of democratic politics; the predicaments of 